\title{
Working at the margins of global production networks: local labour control regimes and rural-based labourers in South India
}

Jonathan Pattenden 1

University of East Anglia - School of International Development, Norwich, UK

\section{Abstract}

This article analyses why informal labourers working 'at the margins' of global production networks lack 'structural' and 'associational' power. It does so in order to better understand potential changes in their material and political conditions, and as part of broader calls to put labour at the centre of development studies. The article focuses on rural-based labourers in south India who work relatively invisibly as agricultural labourers, informal factory workers, and on the construction sites of a 'global city' (Bangalore). It deploys a three-way labour control regime framework that encompasses i) the macro-labour control regime, which is ultimately defined by capitalist relations of production, and characterized in India by particularly high levels of informality (precarious and largely unregulated work) and segmentation (due to the fragmentary impact of caste); ii) the local labour control regime, which refers to how class relations in specific places are shaped by patterns of accumulation and work (themselves shaped by differences in agro-ecology, irrigation, and remoteness from non-agricultural labour markets), distributions of classes and castes, and the uneven presence of the state; and iii) the labour process, which is increasingly marked by forms of 'remote control' marshalled by labour intermediaries. Debate on the macro-labour control regime and on the labour process is well established, but little has been said about local labour control regimes, which are newly defined here and discussed in terms of differences between 'wetland/circulation zones' and 'dryland/commuting zones'. The article identifies locations

1 CONTACT Jonathan Pattenden Email: j.pattenden@uea.ac.uk 
where labour has greater potential structural and associational power. Increased worker organisation in these areas could have knock-on effects in more 'obscure' sites.

\section{Keywords}

Local labour control regimes; class relations; exploitation; India; Karnataka

\section{Introduction: labour at the margins}

The wave of literature on global value chains (GVCs) and global production networks (GPNs) has contributed much to understandings of changing structures of production and geographies of power in contemporary capitalism. ${ }^{1}$ Labour geographers and political economists have sought an increased focus on labour's role within these processes. ${ }^{2}$ It has been argued that labour, 'as the ultimate source of value', must be central to the analysis of global production networks, which are 'as much systems of embodied labour as they are interlinked systems of firms.${ }^{3}$ As well as drawing on labour process theory and its emphasis of 'dynamics of control, consent and resistance at the point of production', ${ }^{4}$ the analysis extends to 'local labour regimes' and 'macro-level political economy'. ${ }^{5}$ In other words connections are made between workplaces, the state and 'broader social structures' and 'economic landscapes' ${ }^{6}$

This article defines 'the margins' of global production networks as sites of production where labourers work informally, relatively invisibly, and with little 'structural' or 'associational' power. ${ }^{7}$ It analyses these conditions in order to better understand potential improvements in labour's material and political conditions. Material conditions refer to poverty (or its absence), while political conditions refer to the capacity for collective organisation in pursuit of shared interests. Explanations of the levels of labour's organisation, its degrees of success, the breadth and sustainability of its impacts, and the search for routes to more fundamental change are central to pro-labouring class analysis. The location of labour within commodity 
chains, ${ }^{8}$ the structure of the chain, ${ }^{9}$ the configuration of class relations at the local level, and the ways in which labour is controlled within production processes all have a bearing on labour's ability to act collectively to defend or advance its position (its 'associational power'). ${ }^{10}$

Capital and labour interact within what is an inherently antagonistic relationship. Capital seeks to maximise productivity while minimising its costs (labour-power and labour embedded in the means of production), in its relentless drive to accumulate. In response, labour, as individuals and collectives, follows strategies of compliance and/or resistance in its search for improved conditions. The interplay of the agency of capital and labour has contrasting and often non-linear outcomes: workers' collective action can prompt gains for labour, ${ }^{11}$ but can also undermine it by re-working spatial and technological fixes in ways that alter the forms and locations of production through outsourcing, subcontracting, and the relocation of production to sites where labour is less organized and wages are lower. ${ }^{12}$

Overt antagonism between classes is characterized by scale and reach. Hence where heightened collective action by workers is more generalized, as in recent years in China, ${ }^{13}$ the responses are more complex and the consequences felt internationally. Short-lived isolated episodes, on the other hand, may not even cause ripples within a district. ${ }^{14}$

The inherent antagonism of the capital-labour relation is embedded in different ways along global value chains, reflecting 'the dialectics of global-local' relations, and its rootedness in the 'territoriality' of concrete socio-political contexts. ${ }^{15}$ These include class-based organisation and interventions by the state (which is understood in this context as a set of institutions expressing contested class relations that are at once locally specific and world-historical). For example, applepickers located at one end of 'buyer-driven' (European supermarket-driven) commodity chains in South Africa have seen deteriorating conditions, ${ }^{16}$ while mostly unionized grapepickers in north-east Brazil supplying European supermarkets have used their proximity to time-sensitive export windows as a basis for heightened bargaining power that has 
contributed to improved conditions. ${ }^{17}$ In West Bengal state investment in irrigation has tightened labour markets and strengthened the socio-political and socio-economic position of some labourers. ${ }^{18}$ Elsewhere, gains and losses are less stable and less clear-cut as capitalists undermine advances made by labour. ${ }^{19}$

As well as a political geography of collective action that has impacts of varying visibility, longevity and import, there is another larger political geography of an absence of labouring class action and organisation. Here labourers work at the margins of global production networks with relatively little associational or structural power. Amongst them are the ruralbased labouring class households that are the subject of this article. Based in villages in two districts in south India (Dharwad and Raichur), they work in i) their home villages, ii) nearby cities that they commute to on a daily basis; or iii) remote cities that they migrate to on a circular basis for a number of months or years (see map). Most of these labouring class households are spread across different sites at any point in time (one member of a household working in a city, for example, while others work in a village), and move across sites as individuals or groups over annual and life cycles. When in their villages they produce a number of different agricultural commodities. As commuting labourers they work informally in formal industries, or on small construction projects. As circular migrants to remote cities they almost all work on the construction of buildings that become key infrastructural inputs in international processes of accumulation as the offices of major international companies, or the apartments of IT workers. ${ }^{20}$

INSERT FIGURE 1 Mapping the three zones of work (villages, nearby cities (Dharwad and Hubli), and remote cities (Bangalore)) (map by Eseld Imms).

Unlike those working a step or two from the shelves of European supermarkets or the clothes racks of high street stores, these workers are largely obscured from view. As agricultural 
labourers at the 'base' of commodity chains ${ }^{21}$ they produce a variety of crops (including paddy and cotton) in a prolonged labour process that is fragmented across time, task and farm. Their contribution is completed once bags of produce have been filled and loaded en route to mill and market. As informal workers in formal sector industries in Dharwad that are partowned by the Indian company Tata (owner of well-known brands like Jaguar) they are employed in peripheral tasks in canteens or as sweepers, and periodically removed when they have almost worked for enough successive months to be entitled to a formalcontract; or they are brought into the factories by labour intermediaries who shield factory owners from pressure to implement labour laws. As construction labourers in Bangalore they leave the worksites before the offices of multinational companies are completed, and their erstwhile labour camps of open toilets and blue plastic tents have been greened for the incoming mostly white-collar workforce.

The labourers in the fieldwork sites are, then, located in obscure parts of agricultural commodity chains, outside of core aspects of the labour process in industry, or between moments of accumulation in the construction sector. Analysis of how they are controlled, and how structural and associational power are denied to them, matters to understanding how increments in labouring class power might be fostered - not least because such informal unorganised labourers form a majority of the Indian population. ${ }^{22}$ The focus here, then, is one step back from how structural power can lay the basis for associational power. Instead the article focuses on how such forms of power might be strengthened where both are largely absent. It concludes by underlining the significance of worksites within the two zones (wetland/circulation and dryland/commuting) that are directly linked to accumulation by international companies. In such locations labour has latent structural power and greater potential for associational power. Where these are realised, there are potential knock-on effects in more 'obscure' parts of the two zones. 
As part of a broader attempt to put labour at the centre of the analysis of capitalist development ${ }^{23}$ the article seeks to better understand how the power of labour might be increased by deploying a three-way characterisation of 'labour control regimes'. This is used to analyse fieldwork data from the two south Indian districts of Raichur in north-east Karnataka and Dharwad in north-west Karnataka (see map). The article draws primarily on data collected in 2013-14, and secondarily on data collected from 2002 to 2011. While the broader fieldwork extended to over 30 villages, the focus here is on the four villages where fieldwork was conducted most recently - two irrigated villages from which labourers circulate to remote cities, and two dryland villages from which they commute. ${ }^{24}$ As the analysis becomes more detailed it becomes increasingly focused on one dryland and one wetland village (in Dharwad and Raichur districts respectively), while discussion of the other two villages provides context within the two districts.

The class-relational approach used here, which is informed by the considerable literature on Indian labour, ${ }^{25}$ labour control, ${ }^{26}$ and labour geography, ${ }^{27}$ emphasises world-historical perspectives on capitalist development. It also goes beyond viewing class-as-stratification (where the focus is on distributions of assets and how that shapes market relations) to analysing social relations at the level of production. ${ }^{28}$ In other words, the emphasis is not just on who has what and what they do with it, but how they get it in the first place.

\section{A three-way approach to labour control regimes}


In order to put labour and class relations at the centre of the analysis of development, this article deploys a three-way approach to labour control regimes to better understand the possibilities for increasing the structural and associational power of people working at the margins of global production networks. This three-way approach is comprised of: i) a macro labour control regime shaped by the broader dynamics of competitive capitalist accumulation within India and beyond; ii) local labour control regimes; and iii) control within the labour process. The first and last aspects of this three-way approach relate to Banaji's distinction between the 'general forms of domination' - understood as the (social) relations of production, or the totality of social relations at different levels in the circuit of capital - and the 'concrete or specific ways' in which capitalists control and deploy labour, which are understood as the immediate relations of exploitation, or forms of exploitation in the labour process. ${ }^{29}$ The intermediate level of the 'local labour control regime' is introduced here in order to elaborate the 'concrete and specific', and to draw out its interplay with the general forms of domination..$^{30}$

As its broadest the 'macro labour control regime' is synonymous with capitalism, and the process of competitive accumulation based on exploitation that is intrinsic to it. Although capitalist labour relations may appear as forms of free exchange in the marketplace, labourers are compelled to enter the market to sell their labour-power as they lack sufficient assets for their material reproduction following gradual processes of socio-economic differentiation, or more dramatic ones of forcible dispossession. Just as compulsion appears as freedom, so exploitation appears as fair exchange since wages obscure the appropriation of surplus value (the basis of accumulation and profit) through surplus labour time - the portion of the day when the labourer is no longer working for the costs of her own reproduction, but for the capitalist. ${ }^{31}$ Surplus-value is not only extracted from labour during the production process, 
but also through rents charged for assets such as land and machinery; and through usury that can facilitate increased extraction of surplus-value in the production process as well as its appropriation through exchange. 'Loans', which act as a form of advance wage that increases access to labour-power, become 'debts' that can be used to press labourers to intensify their work-rate or extend surplus labour time. ${ }^{32}$

Analysis of the labour process focuses on the actual forms of domination and exploitation experienced by rural-based labourers at the level of production, and how these are changing. The 'local labour control regime', ${ }^{33}$ which is the intermediate component of this article's framework, is understood here as being central to how broader capitalist dynamics are 'realised' as actual forms of domination and exploitation within labour processes that shape labour's material and political conditions. In other words, the local labour control regime links the macro labour control regime to actual forms of exploitation. It helps to explain why labourers in the fieldwork villages experience different degrees and forms of domination and exploitation. It does so by drawing into the analysis 'local' patterns of accumulation and labouring class reproduction, distributions of classes and castes (in effect the contemporary expression of past relations), and the most prominent forms of institutional mediation of class relations, which in this article's fieldwork sites are those by local government institutions.

Labouring class reproduction in the fieldwork areas is, as already noted, characterised by a blur of movement of labourers across sites of production. Nevertheless labouring households continue to be based in their home villages, which are therefore seen as the primary location for analysis of how labour control regimes are 'realised' as uneven material and political conditions. Two distinct local labour control regimes emerge from the fieldwork data analysed in this paper - one that is characterised by dryland agriculture and commuting (in the case of the Dharwad villages), and the other by wetland agriculture and circular migration 
(in the case of the Raichur villages). The remainder of the article analyses the labour control regime in these two zones, and seeks out possibilities for collective action by labour.

\section{The macro labour control regime in India}

India's relationship with the world-historical process of capitalist development, along with state policies that have sought to maximize the accumulation of Indian capital and its competitiveness in world markets, ${ }^{34}$ have produced a macro-labour control regime that is characterized by particularly high levels of informality (meaning precarious and largely unregulated work) and segmentation (due to caste divisions). In 2009-10, 423 million of India's total workforce of 460 million (92 per cent) were informally employed, ${ }^{35}$ meaning that they were afforded relatively little protection by social security and labour laws, worked without a written contract, and lacked representation. ${ }^{36}$ During the 2000 s the growth of informal jobs outstripped those of formal jobs by 60 million to 4 million. Over a quarter of the new informal jobs were in the formal sector, underlining how employment characterized by precarity, poor conditions, and low rates of pay is being extended into formal parts of the economy. ${ }^{37}$ Precarity, which is socially regulated by kin, caste and gender relations, as well as by class relations, ${ }^{38}$ is compounded by the presence of a reserve army of labour that 'disciplines and disempowers those in work, discouraging them politically from struggles over the distribution of wages and profits'. ${ }^{39}$ Unskilled workers, who generally receive the lowest wages, are the most vulnerable because they are the easiest to replace and tend to be less likely to organise.

The absence of the state as an enforcer of its own rules on workplaces, and as a facilitator of workers' access to social security, is in itself a form of control as it shapes the labour process in capital's favour. This is a conscious strategy forged by the state's proximity to capital (although not all individual capitals), ${ }^{40}$ and its commitment to supporting capitalist 
accumulation without jeopardising social stability or the supply of labour. The current more stridently neoliberal Bharatiya Janata Party (BJP) government is seeking to further increase levels of informality by raising the thresholds at which capitalists are legally required to implement labour legislation. The Contract Labour Act (which imposes limitations on the employment of contract labour) would apply to establishments with more than fifty workers rather than twenty as is currently the case, while the Factories Act (which includes regulations on health and safety, inspections, annual leave and working hours) would also apply to fewer establishments. ${ }^{41}$ Even though ways are often found to avoid legislation - by outsourcing, subcontracting, or making one production unit appear as two -42 the proposed legislation would further undermine labour's ability to mobilize around the state. It would also worsen its material conditions by intensifying the labour process and increasing exposure to dangerous working and living conditions.

As well as informality and state scarcity, Ind ia's macro labour control regime is characterised by heightened levels of segmentation. Labouring class households are not just integrated into processes of accumulation and exploitation with different levels of intensity, visibility and bargaining power, they are also segmented by increasingly complex geographies of reproduction with most households working in multiple and changing locations, and often combining wage-labour with forms of petty self-employment. ${ }^{43}$ To be more specific, a dwindling proportion of rural-based labouring class households continue to reproduce themselves primarily through agriculture in their home villages, ${ }^{44}$ while a growing number either commute to nearby cities or circulate to distant ones. ${ }^{45}$

Segmentation is not driven solely by structural change. Like informalisation, it is also a conscious capitalist strategy that plays not only on spatial divisions, but also those of gender, task, wage level, religion, language, and caste. Caste is a particularly important form of segmentation in India, and one that cannot be separated from class as it 'entails an ideology that 
explains and legitimates the material differences of class and power relations'. ${ }^{46}$ Where class overlaps more tightly with caste, 'thicker' social ties and loyalties strengthen the capacity of classes (those of both capital and labour) to act collectively. ${ }^{47}$ Greater caste heterogeneity, on the other hand, makes classes of labour easier to control.

When viewed in concrete historical terms, then, class in rural India is not a singular identity but a plural one - in terms of its multiple forms of reproduction, but also in terms of the various axes of inequality/domination embedded within it. ${ }^{48}$ This moves us from the broad frame of competitive capitalist accumulation based on exploitation, and characterised in India by high levels of informality and segmentation, towards the specific forms of class relations in particular locations.

\section{The local labour control regime in rural north Karnataka}

Local labour control regimes are what mark out this paper's contribution to analyses of labour's political and material conditions. They are outlined here through five interrelated variables: i) patterns of accumulation, which are shaped by such things as geophysical variations, and linked to broader contexts through capital flows into and out of the 'local' area; ii) patterns of labouring class reproduction - narrowed down here to focus on the sphere of production, and on wage-labour rather than self-employment because wage-labour is the primary basis of household reproduction in the fieldwork villages; iii) local institutional dynamics - understood here primarily in terms of local government institutions and the ways in which they mediate class relations through the allocation of public resources; iv) the distribution of classes - understood here in the relatively simple terms of landholdings and whether a household is a net buyer or seller of labour power; ${ }^{49}$ and v) the distribution of castes.

The two fieldwork districts are located in historically distinct parts of the state, ${ }^{50}$ and have contrasting development indicators. Raichur has the highest poverty levels in the state of Karnataka, and human development indicators comparable to India's poorest states. Dharwad, 
on the other hand, has poverty levels and HDIs close to state and national averages, ${ }^{51}$ and is also better-connected to major cities and ports. The data that are discussed in this section are based on surveys and interviews in 901 households in four villages (selected according to proximity to non-agricultural labour markets, levels of irrigation, and distributions of landholdings and caste). ${ }^{52}$ They illustrate variations between local labour control regimes, starting with patterns of accumulation.

\section{Patterns of accumulation}

Patterns of capitalist class accumulation and labouring class reproduction in each fieldwork village are shaped by distributions of irrigation, soil type, land, and castes (see Table 1). Higher levels of irrigation and better soils increase agricultural profitability. The two Raichur villages were canal-irrigated - 50 per cent in the case of Jagalwara and over 90 per cent in Shiva Camp. By contrast less than a fifth of the two dryland Dharwad villages were irrigated by borewells, and levels of agricultural profitability were lower. There were also significant differences in soil type - the least irrigated village (Panchnagaram) had mostly less productive red soil, while the second Dharwad village (Kamlapur), like both Raichur villages, had mostly black soil, which retains moisture much more effectively, and allows crops to withstand periods of low rainfall.

\section{INSERT TABLE 1}

Canal-irrigated Shiva Camp's larger agricultural surpluses led to greater investment in agribusiness (such as trading and milling) than in the other three villages combined. Profits from agriculture and agribusiness had financed postgraduate qualifications and formal sector 
city jobs for the next generation ${ }^{53}$ - a trend made clear by data on the primary economic activities of individuals rather than households as a whole (see Table 3).

In Panchnagaram village (in Dharwad district), meanwhile, lower levels of irrigation and poorer soils restricted agricultural accumulation, and encouraged members of its capitalist class to accumulate through the state. Their hand was strengthened by the fact that they were mostly from the same Lingayat caste that was politically dominant in the district as a whole. Of all the fieldwork villages Panchnagaram had the greatest number of public sector employees, the highest number of contractors, and had had more district councillors over the previous two decades. Meanwhile Kamlapur village (also in Dharwad) was dominated by a Maratha caste with little clout at district level. Its capitalist class's accumulation strategies were more firmly linked to agriculture (see table 2). Jagalwara's situation was similar. Accumulation strategies, then, had diversified in Shiva Camp (Raichur) through agribusiness and formal urban employment, and in Panchnagaram (Dharwad) through state-linked accumulation, more than in Jagalwara (Raichur) and Kamlapur (Dharwad), which remained more agriculture-focused (see tables 2 and 3 ). These variations shape interactions between classes in ways that will become apparent.

\section{INSERT TABLES 2 and 3}

Class and caste

Levels of agricultural profitability correlate with levels of class/caste inequality (see Table 4). Shiva Camp, which had the highest levels of irrigation and agricultural profitability, also had the most uneven land distribution. Around 50 per cent of its households were landless, and those that were scheduled caste owned an average of less than half an acre (see Table 5). The Telugu-speaking dominant caste Reddys and Kammas, on the other hand, owned an average of nine irrigated acres. In other words the overlap between dominant caste and capitalist class 
was pronounced. In nearby Jagalwara, larger landholdings were spread across more than one caste, while the largest community numerically (scheduled tribe Nayaks) was highly heterogeneous in class terms. The greater caste cohesion of the capitalist class in Shiva Camp and Panchnagaram than in villages like Jagalwara partially explains their greater economic diversification through agribusiness and politics.

\section{INSERT TABLES 4 and 5}

\section{Local institutional dynamics}

The degree of capitalist class control over local government institutions (LGIs) is closely related to caste/class dynamics. Shiva Camp's dominant castes had relatively little influence beyond the village limits where other castes were more influential. In Kamlapur and Jagalwara the class/caste dynamics were even less favourable from the perspective of the dominant. In Panchnagaram, on the other hand, the greater overlap between caste and class at village/gram panchayat (literally 'village council' but in practice usually a handful of villages)/district level gave its capitalist class greater scope to use public resources for its own economic and political ends, and as a basis of control over labourers who were more segmented in caste terms than in the other villages. ${ }^{54}$

It was in the most iniquitous village of Shiva Camp that the share of public resources reaching the labouring class was at its lowest. NREGS (the National Rural Employment Guarantee Scheme) had not functioned for several years, and a sizeable minority did not have access to government subsidized foodgrains through the Public Distribution System. ${ }^{55}$ The Gram Panchayat office was located some distance away in another village along barely navigable mud roads, and there was a general reluctance to make direct claims of it. In some nearby villages, though, the labouring class's relative cohesion in caste terms had helped it to act collectively to make demands of local government institutions. ${ }^{56}$ Across the fieldwork 
villages as a whole, local government institutions (LGIs) primarily mediated in favour of the capitalist class, but they also provided a basis for counter-moves by the labouring class.

\section{Labouring class reproduction}

Informal wage labour was the primary basis of reproduction for over 80 per cent of labouring class households in the fieldwork villages, self-employment the primary basis for around 15 per cent, and formal employment for less than two per cent (see Table 6). Urban employment provided between one third and two thirds of labouring class households in the Dharwad fieldwork villages. The more tightly integrated into urban labour markets a particular village was, the more better-paid skilled workers it had.

Kamlapur was more tightly integrated into urban labour markets than nearby Panchnagaram, which had a less polarised distribution of land and a greater variety of labouring class reproduction strategies within the village (including greater amounts of petty commodity production) (see Table 2). While the construction sector was the main source of nonagricultural employment in Kamlapur, in Panchnagaram the primary sources were two Tata joint ventures manufacturing buses and construction machinery. Significantly members of capitalist households played a greater role in mediating access to industrial work than was the case for construction work. ${ }^{57}$

\section{INSERT TABLE 6}

The Raichur villages, meanwhile, were beyond commutable distance from any city. A majority of its labouring class households had migrated 500 kilometres to the construction sites of Bangalore at some point in the last decade. A sizeable minority continued to do so on a seasonal or temporary basis. Most were unskilled labourers, some were semi-skilled, and a 
handful had become labour intermediaries - mostly from the dryer village of Jagalwara that had a more established migration stream. ${ }^{58}$

Overall, labouring class reproduction in the Raichur villages was marked by wetland agriculture and circulation, and in the Dharwad villages by dryland agriculture and

commuting. Kamlapur's (in Dharwad) labourers were the least dependent on wage-labour in their home village, while Shiva Camp's (in Raichur) were the most dependent (see Table 6). The labouring class was fragmented across living spaces in the Raichur villages because of circular migration. In Dharwad it was fragmented across a greater number of workplaces. Panchnagaram had the most homogenous and politically influential capitalist class, but the most segmented labouring class. More generally the Raichur villages had a greater degree of caste-based united within the labouring class than was the case in the Dharwad villages. How, then, did these broad variations in class relations interact with forms of domination and exploitation within the labour process to create labour's uneven material and political conditions?

\section{Control within the labour process: comparing labour control regimes in Raichur and Dharwad}

Labour has been identified as having better material conditions and greater bargaining power in areas with stronger links to non-agricultural labour markets, better access to pro-labour state regulations and public welfare programmes, and histories of stronger labouring class organisation. ${ }^{59}$ Labour regimes tend to be harsher in more remote villages where accumulation is more dependent on agriculture, and links to non-agricultural labour markets are weaker. ${ }^{60}$ These are patterns not rules: high levels of control over labour have also been identified in villages closer to urban centres, ${ }^{61}$ and in peri-urban settings. ${ }^{62}$

It is at the level of production that labour control regimes take their concrete form (are imposed on 'labouring bodies'), and that the labour control regimes in the wetland/circulation 
and dryland/commuting zones can be compared. In the less remote dryland village (Panchnagaram in Dharwad) levels of accumulation through agriculture were lower, statelinked forms of accumulation higher, and commuting provided a significant basis of labouring class reproduction. In Shiva Camp (in Raichur) levels of accumulation through agriculture and agribusiness, investment of surpluses outside of the local area were greater, and circular migration was a significant basis of labouring class reproduction (see Table 7).

Labour relations in the irrigated village of Shiva Camp (Raichur), which had the highest levels of poverty, were marked by a re-intensification of direct capitalist control over labour, while in dryland Panchnagaram (Dharwad) they were marked by an intensification of indirect forms of control through the distribution of public resources. In both cases, 'remote control' through intermediaries became more common when labourers worked outside of their villages.

INSERT TABLE 7

Re-intensifying control over labour: the labour control regime in a 'wetland/circulation zone'

Shiva Camp is relatively remote from non-agricultural labour markets. Its wages rise more slowly than road-side villages, and a greater proportion of its population live in extreme poverty, reside in mud houses, withdraw girl children from school to look after siblings, and experience health problems. ${ }^{63}$

In the early 2000 s the combination of a prolonged drought and the mechanisation of paddy harvesting in Shiva Camp i) accelerated the decline of levels of bonded labour, whereby labourers are bound into long-term debt-related 'beck and call' labour relations with particular farmers, and work up to fourteen hours per day, ${ }^{64}$ and ii) triggered a wave of circular migration to the building sites of Bangalore. This loosening of labour relations went 
hand-in-hand with an acceleration of mechanisation (see Table 1), a shift to less labourintensive crops, and the hiring in of paddy transplantation gangs from other areas.

Despite some loosening of labour relations, levels of control over labour remained high. Three forms stood out - sharecropping and piece-rate arrangements at village-level, and 'remote control' in the cities. Sharecropping amounted to highly exploitative forms of piecerated wage-labour, and involved around half of labouring class households (when fieldwork was last conducted in 2014). The 'sharecroppers' worked the land of their main employer and creditor, whose time was thereby freed up to pursue agribusiness ventures. They received inputs 'on credit' from him, transferred the harvest to him, and received their 'share' after input costs and 'interest' had been cut. For the duration of the 'sharecropping' agreement, one household member had to report to the landowner's house every morning to work for around 25 per cent less than the going rate for agricultural labour. ${ }^{65}$ Sharecropping, then, extends the process of exploitation across the household and across time, while interlocking mechanisms (combinations of buying labour-power, lending money to labourers, and trading inputs, output and essential commodities) ratchet up the overall rate of exploitation. ${ }^{66}$

Piece-rate arrangements, which have become increasingly common, reduce the need for direct supervision of labour. In paddy transplantation work the working day is extended and intensified by the fact that wages are based on the area transplanted. Transplantation gangs are self-disciplining: gang leaders and physically stronger members press others to work faster, and exclude slower workers (the elderly, the inexperienced and the infirm). Rather than encouraging each other to 'eat and get strength', the lunch breaks of paddy transplantation gangs are cut short by the words 'hurry and finish food'.

The leaders of paddy transplantation gangs secure work, negotiate rates, pick workers, collect and distribute wages, and influence the pace of work. The farmer's control over a gang (in 
terms of both accessing labour-power and influencing the labour process) rises where he is able to influence the gang leader by providing her with loans or small additional payments. This allows farmers to 'persuade' gang leaders that paddy fields are smaller than they actually are. In other words, good relations with gang leaders are used to 'covertly' lower what are ostensibly fixed rate wages.

The lowest wages in the Raichur villages were paid to its poorest households whose members were forced to ask for work, had the least bargaining power, and at times were even overlooked due to their need for prompt payment of wages. The degree and number of variations in the forms of wage-labour reflect labour's high levels of segmentation, and underline the redundance of crude distinctions between free and unfree labour.

\section{Informality, segmentation and 'remote-control' beyond the village}

Most labouring class households in the Raichur fieldwork villages had circulated to Bangalore for work. Labour intermediaries (maistries) recruited these migrant labourers and often managed them on an everyday basis, providing a buffer between capital and labour, and reifying the spaces of class struggle by filtering demands, absorbing grievances, and reducing the incidence of collective action. Maistries usually recruited from their home areas, thereby reducing the chances of workers foot-dragging or disappearing because their families could be easily traced. Control was even tighter where intermediaries had 'advanced' money to labourers.

'Remote-control' of labour physically detaches capital from labour, and facilitates flexibilisation and informalisation. ${ }^{67}$ Capital sidesteps most labour laws by recruiting through intermediaries, while also being under no compulsion to keep workers in employment. Its responsibilities are blurred by subcontracting chains, and labour has little ability to challenge employers that it would struggle to locate. The combination of informality, intermediation 
and segmentation allows capital to maintain a relatively cheap, pliant and reliable workforce with little direct supervision and the ever-present fall-back of the reserve army of labour lurking both in the city's labour mandis, ${ }^{68}$ and among labour intermediaries' village networks. Although wage-labour was more regular and wages higher in Bangalore than in the countryside, ${ }^{69}$ living conditions were harsher. Circular migrants working on the site of a Special Economic Zone in the north of the city lived in a tent camp, which was divided into sections according to where labourers were from. These workers, who were building the offices of IBM and Nokia (among others), slept on mud floors and defecated beside the path at the edge of their camp. The frequency of illness was widely reported to be greater than in migrants' home villages. Although theoretically eligible, none of the respondents had accessed any of a range of government social security measures including the health-related provisions of the 2008 Unorganised Workers and Social Security Act (UWSSA). ${ }^{70}$ Had they been implemented none of the migrant labourers would have seen their socio-economic situation deteriorate as a result of migration. As it was, half of them did.

\section{Linking the levels}

The state is present in its absence from Bangalore's construction sector. Its withdrawal from the enforcement of labour legislation shapes both the material conditions of labour and the competitiveness of capital. The state and construction capital share an interest in relatively cheaply produced commercial and domestic infrastructure, which increases accumulation in the real estate sector and provides relatively cheap rents for tenants like IBM, and for their employees. Like garment workers supplying high street stores, migrant construction workers contribute to the accumulation processes of well-known global brands, but their work is relatively invisible because it is completed before IBM move in. Unlike garment workers whose exploitation continues during the accumulation processes of well-known companies, 
there is a 'temporal rupture' between the exploitation of construction workers and the appropriation of surplus-value by companies like IBM. Consequently labourers' latent structural power does not materialise, and they are left exposed to the kinds of working and living conditions that shorten lives.

Links between the state and the construction sector also take more specific forms - through the lobbying efforts of construction industry associations, for example; or through the fact that some MLAs (Members of the Legislative Assembly) have built their political careers through the construction sector and so can provide a legislative 'beach-head' for industry lobbyists; or through the more prosaic everyday interactions through which labour department officials and industry managers are complicit in the evasion of state regulations on the ground. ${ }^{71}$ The bluntness of the regulatory regime was underlined by Labour Department officials in Bangalore. Unable to enforce legislation, they had asked construction companies to comply with regulations of their own accord. ${ }^{72}$

In Bangalore, then, labourers found their living and working conditions shaped by the broader capitalist dynamics of the macro capitalist control regime - accumulation in a competitive world capitalist system manifested in its political form through pro-capital state practices that create and maintain informal flexible working places, dangerous labour processes, and poor living conditions with no meaningful outlet for grievances.

The labour control regime affecting migrant construction workers encompasses their home villages as well as Bangalore. Given Shiva Camp's relatively steep social hierarchies and the almost complete subordination of its Gram Panchayat to the capitalist class, circular migration to Bangalore was a key means of contesting class relations. This in turn prompted farmers to re-work forms of control over labour, and to prevent some labourers from leaving through the renewal of debt-related ties and sharecropping arrangements (as outlined above). 
At the same time growing levels of mechanisation and a diversification of accumulation strategies out of the village continue to reinforce outmigration by reducing employment in the village. . The key point is that the three levels of the labour control regime are interrelated across the wetland/circulation and dryland/commuting zones, and each level has to be analysed in each zone in order to understand differences in the labour process and the unevenness of material and political conditions.

Reproducing domination through the state: the labour control regime in a 'dryland/commuting zone'

The labour control regime in Panchnagaram (Dharwad), which is located in a 'dryland/commuting zone', differs from that of Shiva Camp. Its farmers' ability to control male workers through labour relations was weakened by labourers' easy access to nonagricultural labour markets. This was evident in farmers' perceptions of their declining ability to control labour and maintain the intensity of the labour process. For example, a large landowner from a Dharwad village that was slightly closer to the city than Panchnagaram lamented the tightening of labour markets and the fact that there was now less scope to 'pick and choose the best workers'. In a partially canal-irrigated village that was considerably further from the city (just beyond commutable distance), farmers made no reference to nonagricultural employment, but pointed the finger very firmly at 'bogus' government schemes by which they primarily meant the recent (2013) expansion of the public distribution system (of subsidised foodgrains), and, to a lesser degree, NREGS (employment on public works ). Prominent local councillors joked about the fact that NREGS remained largely unimplemented during a public discussion in the gram panchayat office. ${ }^{73}$ 
Back in Panchnagaram village, where accumulation strategies were somewhat more diversified, large farmers were not unduly concerned about government programmes and pointed to the growth of ind ustrial employment as the primary 'problem'. Here, compared to Shiva Camp in Raichur, there were i) fewer cases of bonded labour; ii) more cases of land leased on a cash basis rather than on a sharecropping basis; ${ }^{74}$ iii) fewer agricultural machines and a slower shift to less labour-intensive crops (both of which are in part a means of disciplining labour); and iv) more sources of credit (including employers in the town and labour intermediaries, of whom there were more than in the circulation stream between Raichur and Bangalore).

The capitalist class's response to its declining levels of direct control over labour in Panchnagaram's sphere of production was three-fold. Firstly it acted as gatekeeper to some forms of non-agricultural employment (those in industry rather than those in construction). Secondly it increased its control over female labourers. ${ }^{75}$ Thirdly it used its control over the distribution of public resources through local government institutions to heighten its control over labour's reproduction. ${ }^{76}$ The execution of this strategy was made easier by the relative caste-cohesion and broader political influence of Panchnagaram's dominant class. Its significance was underlined by women from the poorest households in the village expressing fear about losing their 'ration cards' (that provide access to government-subsidised foodgrains through the 'Public Distribution System'), which were all that stood between them and chronic under-nutrition. During the 2000s Gram Panchayat budgets had increased tenfold and amounted, by the end of the decade, to more than one third of below poverty line incomes. Dependence on those distributing public resources had never been greater.

Even those labouring class households that were somewhat better off and more independent of the village said that there was no point in rocking the boat, which was seen both as futile and a sure way to undermine access to public resources in the future. Meanwhile, underlining 
that labour control regimes do not only represent an entanglement of contested social relations, but also perceptions of those relations, politically influential men projected their power by inviting prominent local politicians to their homes - part of the process of maintaining control over labour without bearing the full costs of its reproduction. ${ }^{77}$ Two conclusions can be drawn: uneven distributions of public resources (both at a given point in time, and over time) segment and discipline labour, ${ }^{78}$ and perceptions of power permeate the production process even while appearing to be external to it.

Like the circular migrants in Bangalore, Panchnagaram's commuters usually accessed work in the city through intermediaries. Those working in construction generally did so through fellow members of the labouring class, while access to industrial work was largely mediated by members of the dominant class/caste. These intermediaries shielded Tata from its responsibilities as a formal sector employer. Over ninety per cent of those working in its factories were informally employed, and although most had payments for social security deducted from their wages, in practice less than ten per cent had actually accessed social security payments. Most were either periodically laid-off to keep their employment informal, or they worked on a seasonal or part-time basis anyway.

Commuting labourers in Dharwad were segmented across a greater number of worksites and sectors than their circulating counterparts in Bangalore. Moreover access to non-agricultural employment was often segmented along lines of caste and religious community. ${ }^{79}$ Living conditions, though, were notably better - almost all Dharwad commuters lived in concrete houses and had access to Public Distribution System (government subsidised) foodgrains. Largely absent in the worksites, the state re-emerges in Dharwad's villages to mediate class relations. It provides resources for both capital and labour, and helps to forestall the chances of labour mobilising in pursuit of its interests. 


\section{Local labour control regimes and socio-political change}

There are similarities and differences in the ways in which commuting and circulation shaped class relations at village level. In remote irrigated Shiva Camp, where agriculture is more profitable, labour was more tightly controlled - through greater dependence on village-based wage-labour and credit, and weaker mediation of class relations by state programmes. Steep social hierarchies at village-level heightened the significance of non-agricultural employment as a basis for challenging the status quo at home. They also limited the possibilities for more individualised negotiations with capital. Contestation of class relations in Shiva Camp requires collective action - something that had happened in the area through an organisation of female labourers who were almost all from the most numerous caste within the labouring class. ${ }^{80}$

Circular migration from Shiva Camp had triggered slight socio-political gains. On their return home from Bangalore, many labourers appeared more assertive, emboldened by experiences elsewhere and a reduced dependence on capitalist farmers at home. Socio-political gains were, though, dissipated by the ongoing process of circulation, which scattered workers between the countryside and the city, making any collective impetus for change unlikely. Spatial segmentation, in other words, forestalls sustained collective action by the labouring class, and socio-political gains are more likely to be episodic, discursive, and symbolic than embedded or sustained.

Elsewhere in the 'wetland/circulation zone', labourers' latent structural power, which is derived from their 'imminent' contribution to the profits of prominent international companies like IBM, remained unrealised. Their bargaining power with regard to construction capital was almost non-existent. Living and working conditions were poor, social security provisions generally unfulfilled, and government regulations routinely flouted. 
Nevertheless, in the labour camp, younger married men, who had formerly been bonded labourers, were unequivocal in their preference for being in Bangalore away from demeaning relations with landlords.

Like their counterparts in Bangalore, the latent structural power of commuters in the Dharwad village, which was derived from their working for the well-known international company Tata, remained unrealised - stymied by segmentation, informality and 'remotecontrol'. Village-level socio-political gains accruing from commuting (which reduced dependence upon dominant village households) were not dissipated by the spatial segmentation that constrained circular migrants. Patterns of access to urban labour markets were reflected in labouring class critiques of the village's dominant men, and a clearly stated desire not to work for them. Such criticisms were most clearly articulated in those communities (castes or religious groups) with the highest levels of commuting, while labouring class households that were more dependent on the village economy and received a greater share of resources from gram panchayat-administered programmes were unlikely to be critical. ${ }^{81}$

Although non-agricultural employment had brought slight economic and socio-political gains across both the 'wetland/circulation zone' and the 'dryland/commuting zone', classes of labour remained segmented and unorganized, while the capitalist class was better able to project its interests - by sidestepping labour regulations in the cities, by re-working its control over labour in the villages (either directly or through control over local government institutions); and through the widespread use of debt-based control. 


\section{Conclusion}

Informal labour working at the margins of global production networks has little associational and structural power. This article has developed and deployed a three-way approach to labour control regimes, which includes analysis of the local labour control regime, to unravel the mechanisms that constrain labour's political and material position, and the possibilities for change. Although lacking associational and structural power, informal labourers in Ind ia have numbers on their side as they constitute a majority of the population. In addition, Indian labour's growing significance to the world economy is likely to increase its structural power - particularly as China begins to move away from low-waged production, opening the way for India to follow its global presence in the services sector with an expansion of its role in manufacturing. In this context, the kind of latent structural power referred to above - through working directly or indirectly for companies like Tata and IBM - is likely to increase.

Each of the three levels of the labour control regime framework explored in this paper sheds light on how structural and associational power can be augmented. Macro labour control regimes are critical to locating Indian labour in its world-historical context. In general terms this means that it is subject to capitalism's compulsion to exploit and accumulate in a global context. In more specific terms, it is subject to particularly high levels of informality because these lower labour costs and enhance the competitiveness of India's fast-growing economy.

While the macro labour control regime explains Indian labour's position in broad terms, it does not account for the marked differences in labour's material conditions, and its ability to act collectively in its interests and affect pro-labouring class change (its political conditions). Analysis of the local labour control regime, which is in effect a prism of intersecting determinations including distributions of land and castes, levels of irrigation and soil types, and patterns of capitalist class accumulation and labouring class reproduction (in other words 
the broad patterns of class relations), is critical for explaining these variations, and for developing pro-labour strategies that are sensitive to the specificities of class relations in particular places while being part of broader movements.

The state in India promotes informality by avoiding mediation of class relations at the level of production through the enforcement of labour standards or the provision of social 'insurance'. Instead, it subsidises labour's reproduction in order to protect social stability, reduce capital's labour costs, and facilitate global competitiveness. The uneven ways in which it mediates class relations through public employment and other programmes reflects the local labour control regime. In the fieldwork villages those mediations tend to strengthen the position of the dominant, while also contributing to counter-moves to advance the position of labour.

Forms of control at the level of production, while shaped by the labour control regime as a whole, take on specific forms within the performance of time-rated, piece-rated and subcontracted wage-labour. More directly coercive forms of control over labour were associated with more remote (and irrigated) villages with steeper social and economic hierarchies, weaker access to non-agricultural employment and government programmes, and greater levels of poverty. Meanwhile more indirect forms of control (through access to government resources and employment in industry) were associated with villages with stronger access to non-agricultural labour markets.

'Remote control', or the growing intermediation of labour relations that physically distances capitalists from labourers, reflects the changing spatial patterns of competitive accumulation and simple reproduction. Where the links between village and urban labour market are diffuse, as in some Dharwad villages, labour is less tightly controlled than in the longer and 'narrower' channels between village and city in Raichur. 
Analysis of the local labour control regime has been central to the tentative conclusions about pro-labouring class strategy based on this article's comparative analysis of 'wetland/circulating' and 'dryland/commuting' zones. In the Raichur villages steeper social hierarchies make less direct forms of struggle around access to state programmes the most feasible form of action. In Panchnagaram (Dharwad), the search for access to social security in Tata's formal sector workplaces is a potential source of collective action. Tata's global visibility accords those working for it the kind of structural power that workers on Dharwad's many small construction sites lack. The concretisation of this structural power would require concerted union organising. Similar claims by unskilled circular migrants in Bangalore would not only require union organising, but, given that this is such hostile terrain for labouring class organisation, would also need the mobilisation of a greater number of national and international allies.

This article's main argument, which has been made implicitly throughout the paper, is essentially about method. The conclusions reached, which are based on analysis of the labour control regime, do not offer any blueprint or typology, nor do they necessarily indicate the most appropriate pro-labouring class strategies in Dharwad and Raichur, which will change over time. What they do seek to underline is a method of analysis that is sensitive to the 'local' specificities of class relations; which responds to the dynamism of class struggle; and which moves between the particular and the general rather than simply using case studies to inform broader arguments. In other words, instead of a single movement from one level of analysis to another there should be a constant movement between all levels of analysis.

It is valid but somewhat banal to state that finding ways to strengthen the organisation of informal workers (in part by analysing multi-layered labour control regimes) is critical for the material and political conditions of labourers working at the margins of global production networks. Research aimed at reducing the degrees of violence of everyday labour relations in 
contemporary India requires more precision. This article has sought to increase the visibility of migrant construction workers, 'floating' industrial workers, and those whose labour is scattered across unseen fields. It has sought to make their links to broader processes of surplus-value creation a little more obvious, and their routes to greater structural and associational power a little clearer. In order to do so it has developed the notion of the local labour control regime, and attempted to move between exploitation at the level of production and the world-historical dynamics of competitive capitalist accumulation.

\section{Acknowledgements}

The author would like to thank Savitri for invaluable research assistance, as well as an anonymous reviewer and his fellow editors for comments on an earlier draft.

\section{Notes on Contributor}

Jonathan Pattenden is author of Labour, State and Society in Rural India: A Class-Relational Approach (Manchester University Press, 2016). His research on the political economy and political sociology of development and class relations in India has been published in Development and Change, the Global Labour Journal, the Journal of Peasant Studies, Economic and Political Weekly and the Journal of Agrarian Change. His current research focuses on labourers in the construction sector. He is Lecturer in Politics and Development Studies at the University of East Anglia. 


\section{Bibliography}

Agarwala, Rina. Informal Labor, Formal Politics, and Dignified Discontent in India. Cambridge: Cambridge University Press, 2013.

Anner, Mark. "Labor Control Regimes and Worker Resistance in Global Supply Chains". Labor History 56, no.3 (2015): 292-307.

Bair, Jennifer. "Analysing Global Economic Organisation: Embedded Networks and Global Chains Compared". Economy and Society 37, no.3 (2008): 339-364.

Banaji, Jairus. Theory as history: essays on modes of production and exploitation. Chicago: Haymarket Books, 2010.

Barrientos, Stephanie, and Andrienetta Kritzinger. "Squaring the Circle: Global Production and the Informalization of Work in South African Fruit Exports". Journal of International Development 16 (2004), 81-92.

Bernstein, Henry. "Is There an Agrarian Question in the Twenty-First Century?" Canadian Journal of Development Studies 27, no. 4 (2006): 449-60.

Bernstein, Henry. Class Dynamics of Agrarian Change. Halifax: Fernwood and Sterling, VA: Kumarian, 2010.

Bharadwaj, Krishna. "A view on commercialisation in Indian agriculture and the development of capitalism”. Journal of Peasant Studies 12, no.4 (1985): 7-25.

Bourdieu, Pierre. The Logic of Practice. Cambridge: Polity, 1990.

Braverman, Henry. Labor and Monopoly Capital: The Degradation of Work in the Twentieth Century. New York: Monthly Review Press, 1974.

Brass, Tom. "Class Struggle and the Deproletarianisation of Agricultural Labour in Haryana (India)". Journal of Peasant Studies 18, no.1 (1990): 36-65.

Breman, Jan. Footloose labour: working in India's informal economy. Cambridge: Cambridge University Press, 1996.

Breman, Jan. 2007 Labour Bondage in West India: from Past to Present. Oxford: Oxford University Press.

Breman, Jan, and K.P. Kannan, eds. The Long Road to Social Security. New Delhi: Oxford University Press, 2013.

Burawoy, Michael. The Politics of Production. London: Verso, 1985.

Business Standard "Rajasthan Assembly passes labour law changes". Business Standard, 1 August. Online: www.business-standard.com/article/economy-policy/rajasthan-assembly-passes-four-labourreform-bills-114073101662_1.html, 2014.

Campling, Liam. "Debating modes of production and forms of exploitation: introduction to the symposium on Jairus Banaji's Theory as History”, Historical Materialism 21, no. 4 (2013): 3-10. 
Carswell, Grace, and Geert De Neve, "From Field to Factory: Tracing Transformations in Bonded Labour in the Tiruppur Region, Tamil Nadu". Economy and Society 42, no.3 (2013): 430-54.

Carswell, Grace, and Geert De Neve. "MGNREGA in Tamil Nadu: a Story of Success and Transformation?" Journal of Agrarian Change 14, no. 4 (2014): 564-85.

Castree, Noel, Neil Coe, Kevin Ward, and Michael Samers. Spaces of Work: Global Capitalism and Geographies of Labour. London, Thousand Oaks and New Delhi: Sage, 2004.

Coe, Neil. "Geographies of Production III: Making Space for Labour". Progress in Human Geography 37, no. 2 (2012): 271-284.

Da Corta, Lucia, and Davuluri Venkateshwarlu. "Unfree relations and the feminisation of agricultural labour in Andhra Pradesh, 1970-95". Journal of Peasant Studies 26, nos. 2-3 (1999): 71-139.

Das, Raju. "Reconceptualizing Capitalism: Forms of Subsumption of Labor, Class Struggle, and Uneven Development". Review of Radical Political Economics 20, no. 10 (2011): 1-23.

Epstein, T.Scarlett. South India - yesterday, today and tomorrow: Mysore villages revisited. London: Macmillan, 1973.

Gereffi, Gary. "The Organisation of Buyer-driven Global Commodity Chains: How US Retailers shape Overseas Production Networks". In Commodity Chains and Global Capitalism, edited by Gary Gereffi and M Korzeniewicz. Westport, CT: Greenwood Press, 1994.

Gereffi, Gary, J. Humphrey, and T. Sturgeon. "The governance of global value chains". Review of International Political Economy 12, no.1 (2005):78-104.

Gibbon, Peter, Jennifer Bair, and Stefano Ponte. "Governing Global Value Chains: an Introduction". Economy and Society 37, no.3 (2008): 315-338.

Gooptu, Nandini, and Barbara Harriss-White. "Mapping India's world of unorganised labour”. Socialist Register 37 (2001).

Government of Karnataka (GoK). Karnataka State Gazetteer. Bangalore: Government of Karnataka, 1989.

Guerin, Isabelle with G. Venkatasubramanian. "Corridors of migration and chains of dependence: brick kiln mouldersin Tamil Nadu". In India's Unfree Workforce: of Bondage Old and New, edited by Jan Breman, Isabelle Guérin and Aseem Prakash, 170-97. Delhi: Oxford University Press, 2009.

Harriss, John. "Reflections on Caste and Class, Hierarchy and Dominance". Seminar. Accessed 3 August 2014, http://www.indiaseminar.com/2012/633.htm.

Harriss-White, Barbara. India Working, Essays on Society and Economy. Cambridge: Cambridge University Press, 2003. 
Harriss-White, Barbara. "Capitalism and Poverty". Economic and Political Weekly 41, no. 13 (2006): $1241-1246$

Harriss-White, Barbara. Rural Commercial Capital: Agricultural Markets in West Bengal. New Delhi: Oxford University Press, 2008.

Harriss-White, Barbara. "Work and Wellbeing in Informal Economies: The Regulative Roles of Institutions of Identity and the State". World Development 38, no.2 (2010):170-183.

Harriss-White, Barbara, and Valentina Prosperi, V, 2014. "The Micro Political Economy of Gains by Unorganised Workers in India". Economic and Political Weekly 49 (9): 39-43.

Heller, Patrick. The Labor of Development: Workers and the Transformation of Capitalism in Kerala, India. Ithaca, NY: Cornell University Press, 1999.

Henderson, Jeffrey, Peter Dicken, Martin Hess, Neil Coe, and Henry Wai-Chung Yeung. "Global Production Networks and the Analysis of Economic Development". Review of International Political Economy 9, no.3 (2002): 436-464.

Hensman, Rohini. Workers, Unions, and Global Capitalism: Lessons from India. New York: Colombia University Press, 2011.

Herod, Andrew. Labour Geographies: Workers and the Landscapes of Capitalism. New York: Guilford Press, 2001.

Herod, Andrew. "Labour Geography: Where Have We Been? Where should We go?" In Missing Links in Labour Geography, edited by Ann Cecilie Bergene, Sylvi B. Endresen and Hege Merete Knutsen. London: Ashgate, 2010.

Heyer, Judith. "Labour Standards and Social Policy: A South Indian Case Study". Global Labour Journal 3, no. 1 (2012): 91-117.

Himanshu. "Employment trends in India: a re-examination ". Economic and Political Weekly 46, no. 37 (2011): $43-59$.

Indian Express 'Rajasthan shows way in labour reforms', Indian Express, 8 June. Accessed 11 September 2014, http://ind ianexpress.com/article/india/india-others/ rajasthan-shows-wayin-labour-reforms, 2014.

Jonas, A. "Local labour control regimes: uneven development and the social regulation of production". Regional Studies 30, no. 4 (1996): 323-338.

Kapadia, Karin. "Mutuality and competition: female landless labour and wage rates in Tamil Nadu". Journal of Peasant Studies 20, no. 20 (1993): 296 - 316.

Kapadia, Karin. Siva and Her Sisters: Gender, Caste and Class in Rural South India. Boulder: CO: Westview Press, 1995

Lerche, Jens. "Politics of the Poor: Agricultural Labourers and Political Transformations in Uttar Pradesh”. Journal of Peasant Studies 26, Nos. 2-3 (1999): 182-241.

Marx, Karl. Capital: A Critique of Political Economy Volume I. London: Penguin, 1976. 
Mosse, David, Sanjeev Gupta and Vidya Shah. "On the Margins in the City: Adivasi Seasonal Labour Migration in Western India”. Economic and Political Weekly 40, no. 28 (2005): 3025-3038.

National Commission for Enterprises in the Unorganised Sector [NCEUS]. Report on conditions of work and promotion of livelihoods in the unorganized sector. New Delhi: NCEUS, 2007.

Newsome, Kirsty, Phil Taylor, Jennifer Bair and Al Rainnie. Putting Labour in its place: Labour Process Analysis and Global Value Chains. Basingstoke: Palgrave, 2015

Patnaik, Utsa. "Class Differentiation within the Peasantry: an Approach to Analys is of Indian Agriculture”. Economic and Political Weekly 11, no. 39 (1976): A82-A101.

Pattenden, Jonathan. "Gatekeeping as Accumulation and Domination: Evidence from South India”. Journal of Agrarian Change 11, no. 2 (2011a): 164-94.

Pattenden, Jonathan. "Social Protection and Class Relations: Evidence from Scheduled Caste Women's Associations in Rural South India". Development and Change 42, no. 2 (2011b): 469-98.

Pattenden, Jonathan. "Migrating between Rural Raichur and Boomtown Bangalore: Class Relations and the Circulation of Labour in South India". Global Labour Journal 3, no. 1 (2012): 163-90.

Pattenden, Jonathan. Class and Social Policy: the National Rural Employment Guarantee Scheme in Karnataka, India. Journal of Agrarian Change (published on early view, 2015).

Pattenden, Jonathan. Labour, State and Society in Rural India: A Class-Relational Approach. Manchester: Manchester University Press, 2016.

Peck, James. Workplace: the social regulation of labor markets. New York: Guilford Press, 1996.

Picherit, David. "The Shaping of Labour Struggles from Village to Migration Sites: Labour Standards, Rural Development and Politics in South India”. Global Labour Journal 3, no. 1 (2012): 143-62.

Pringle, Tim. Trade Unions in China: The Challenge of Labour Unrest. London: Routledge, 2011.

Rainnie, Al, Susan McGrath-Champ, and Andrew Herod. "Making Space for Geography in Labour Process Theory". In Working Life: Renewing Labour Process Analysis, edited by Paul Thompson and Chris Smith, 11-28. Basingstoke: Palgrave Macmillan, 2010.

Rainnie, Al, Andrew Herod, and Susan McGrath-Champ. "Review and Positions: Global Production Networks and Labour". Competition and Change 15, no.2 (2011): 155-169.

Ramachandran, V.K. Wage Labour and Unfreedom in Agriculture: An Indian Case Study. Oxford: Clarendon, 1990. 
Rawal, Vikas."The Labour Process in Rural Haryana (India): A Field-Report from Two Villages". Journal of Agrarian Change 6, no. 4 (2006): 538-83.

Riis gaard, Lone, and Nikolaus Hammer. "Prospects for Labour in Global Value Chains: Labour Standards in the Cut Flower and Banana Industries”. British Journal of Industrial Relations 49, no. 1 (2011): 168-190.

Roesch, Marc, G. Venkatasubramanian, and Isabelle Guerin. "Bonded Labour in Rice Mills: Fate or Opportunity?" in India's Unfree Workforce: Of Bondage Old and New, edited by Jan Breman, Isabelle Guerin, and Aseem Prakash, 284-311. Delhi: Oxford University Press, 2009.

Rogaly, Ben, Jhuma Biswas, Daniel Coppard, Abdur Rafique, Kumar Rana and Amrita Sengupta, 'Seasonal Migration, Social Change and Migrants' Rights: Lessons from West Bengal'. Economic and Political Weekly 36, no. 49 (2001): 4547-4559.

Selwyn, Ben. "Labour Flexibility in Export Horticulture: A Case Study of North-East Brazilian Grape Production”. Journal of Peasant Studies 36, no. 4 (2009):761-782.

Selwyn, Ben. The Global Development Crisis. Cambridge: Polity, 2014

Silver, Beverley. Forces of Labour: Workers' Movements and Globalization since 1870. Cambridge: Cambridge University Press, 2003.

Smith, Adam. The Wealth of Nations Books I-III. London: Penguin,1970 [1776].

Srivastava, Ravi. "Tenancy Contracts During Transition: A Study Based on Fieldwork in Uttar Pradesh". Journal of Peasant Studies 16, no. 3 (1989):339-95.

Srivastava, Ravi. "Changing Employment Conditions of the Indian Workforce and Implications for Decent Work". Global Labour Journal 3,no. 1(2012):63-90.

Thomas, J.J. 'India's Labour Market During the 2000s: Surveying the Changes". Economic and Political Weekly 47,no. 51 (2012):39-51.

Thompson, Paul, and Chris Smith. "Debating Labour Process Theory and the Sociology of Work". In Working Life: Renewing Labour Process Analysis, edited by Paul Thompson and Chris Smith, 11-28. Basingstoke: Palgrave Macmillan, 2010.

UNDP. Karnataka Human Development Report 2005. Bangalore: Government of Karnataka Planning and Statistics Department, 2005.

Wright, Erik Olin. "Working-Class Power, Capitalist-Class Interests and Class Compromise". American Journal of Sociology 105, no.4 (2000):957-1002. 
Table 1: Characteristics of fieldwork villages (source: fieldwork data).

\begin{tabular}{|c|c|c|c|c|}
\hline Village Name & $\begin{array}{l}\text { Panchnagaram } \\
\text { (Dharwad) }\end{array}$ & $\begin{array}{l}\text { Kamlapur } \\
\text { (Dharwad) }\end{array}$ & $\begin{array}{l}\text { Shiva Camp } \\
\text { (Raichur) }\end{array}$ & $\begin{array}{l}\text { Jagalwara } \\
\text { (Raichur) }\end{array}$ \\
\hline Distance from city & 12 & 12 & 100 & 75 \\
\hline $\begin{array}{ll}\text { Distance } & \text { from } \\
\text { Industrial Park } & \end{array}$ & 7 & 18 & n.a & n.a \\
\hline Land Value & Highest & $2^{\text {nd }}$ & $3^{\text {rd }}$ & Lowest \\
\hline $\begin{array}{l}\% \text { of land irrigated } \\
\text { (and type) }\end{array}$ & 12 (Borewell) & 18 (Borewell) & 96 (canal) & $\begin{array}{l}52 \\
\text { (Canal/river) }\end{array}$ \\
\hline Soil Type & Mostly red & Mostly Black & $>90 \%$ black & $>90 \%$ black \\
\hline $\begin{array}{l}\text { Profitability } \\
\text { Agriculture }\end{array}$ & Lowest & & Highest & \\
\hline $\begin{array}{l}\text { Prevalence of } \\
\text { Accumulation } \\
\text { through agribusiness }\end{array}$ & & & Highest & \\
\hline $\begin{array}{l}\text { Prevalence } \\
\text { Accumulation } \\
\text { through state }\end{array}$ & \begin{tabular}{|l|} 
Highest \\
\end{tabular} & & & \\
\hline $\begin{array}{l}\text { Head of Oxen (as a } \\
\text { proxy } \\
\text { mechanisation) }\end{array}$ & 0.5 & 0.5 & $\begin{array}{l}0.2 \quad \text { (most } \\
\text { mechanised) }\end{array}$ & 0.4 \\
\hline $\begin{array}{l}\text { Principal Form of } \\
\text { Non-Agricultural } \\
\text { Employment }\end{array}$ & $\begin{array}{l}\text { Commuting } \\
\text { (Industry) }\end{array}$ & $\begin{array}{l}\text { Commuting } \\
\text { (Construction) }\end{array}$ & $\begin{array}{l}\text { Circular } \\
\text { Migration } \\
\text { (Construction) }\end{array}$ & $\begin{array}{l}\text { Circular } \\
\text { Migration } \\
\text { (Construction) }\end{array}$ \\
\hline
\end{tabular}

Table 2: Distribution of primary bases of accumulation among capitalist households (source: fieldwork data).

\begin{tabular}{|l|l|l|l|l|}
\hline & $\begin{array}{l}\text { Panchnagaram } \\
\text { (Dharwad) }\end{array}$ & $\begin{array}{l}\text { Kamlapur } \\
\text { (Dharwad) }\end{array}$ & $\begin{array}{l}\text { Shiva Camp } \\
\text { (Shiva Camp) }\end{array}$ & $\begin{array}{l}\text { Jagalwara } \\
\text { (Shiva Camp) }\end{array}$ \\
\hline Formal Business & 0 & 0 & 2.5 & 0 \\
\hline $\begin{array}{l}\text { Informal } \\
\text { Business }\end{array}$ & 8.7 & 2.7 & 10.3 & 2 \\
\hline $\begin{array}{l}\text { Regular Formal } \\
\text { Employment }\end{array}$ & 6.2 & 4.8 & $\begin{array}{l}10.2 \text { (mostly } \\
\text { non-local) }\end{array}$ & 0 \\
\hline $\begin{array}{l}\text { Public Sector } \\
\text { Employment }\end{array}$ & 7.1 & 2.7 & 5 & 2 \\
\hline $\begin{array}{l}\text { Mix of non- } \\
\text { agricultural } \\
\text { petty } \\
\text { commodity } \\
\text { production and } \\
\text { farming }\end{array}$ & 4.1 & 4.8 & 5 & 5 \\
\hline Farming & 73.8 & & & 91 \\
\hline Total & 100 & 85 & 67 & 100 \\
\hline
\end{tabular}


Table 3: Number of individuals as percentage of total number of households involved in various economic activities (not including farming where farming is main occupation) (source: fieldwork data).

\begin{tabular}{|l|l|l|l|l|}
\hline & $\begin{array}{l}\text { Panchnagaram } \\
\text { (Dharwad) }\end{array}$ & $\begin{array}{l}\text { Kamlapur } \\
\text { (Dharwad) }\end{array}$ & $\begin{array}{l}\text { Shiva Camp } \\
\text { (Raichur) }\end{array}$ & $\begin{array}{l}\text { Jagalwara } \\
\text { (Raichur) }\end{array}$ \\
\hline Formal Business & 0 & 0 & $2.5 / 6$ & 0 \\
\hline $\begin{array}{l}\text { Informal } \\
\text { Business }\end{array}$ & 10.7 & 8.8 & 48.8 & 4.1 \\
\hline $\begin{array}{l}\text { Regular Formal } \\
\text { Employment }\end{array}$ & 8.9 & 10.8 & $\begin{array}{l}36.7 \quad \text { (mostly } \\
\text { non-local) }\end{array}$ & 1 \\
\hline $\begin{array}{l}\text { Regular } \\
\text { Informal } \\
\text { Employment }\end{array}$ & 1.8 & 2.4 & 17.1 & 0 \\
\hline $\begin{array}{l}\text { Public Sector } \\
\text { Employment }\end{array}$ & 9.8 & 4.4 & 7.3 & 2 \\
\hline $\begin{array}{l}\text { Mix of non- } \\
\text { agricultural } \\
\text { petty } \\
\text { commodity } \\
\text { production and } \\
\text { farming }\end{array}$ & 19.6 & 10.8 & 9.9 & 10.2 \\
\hline
\end{tabular}

Table 4: Distribution of land in the four fieldwork villages (source: fieldwork data)

\begin{tabular}{|l|l|l|l|l|l|}
\hline $\begin{array}{l}\text { Amount of } \\
\text { Land (Acres) }\end{array}$ & Type of Land & Panchnagaram & Kamlapur & $\begin{array}{l}\text { Shiva } \\
\text { Camp } \\
\text { (Dharwad) }\end{array}$ & $\begin{array}{l}\text { Jagalwara } \\
\text { (Raichur) }\end{array}$ \\
\hline $10+$ & Mostly irrigated & & & 7.6 & 2 \\
\hline & Mostly dry & 3.9 & 11.3 & & 4 \\
\hline $5-10$ & Mostly irrigated & & & 10 & 3.6 \\
\hline & Mostly dry & 9.2 & 11.9 & & 6.9 \\
\hline $2.5-5$ & Mostly irrigated & & & 9.4 & 8.3 \\
\hline $0-2.5$ & Mostly dry & 19 & 10.6 & & 8.3 \\
\hline & Mostly irrigated & & & 23.4 & 21.7 \\
\hline 0 & Mostly dry & 36.9 & 20.5 & & 28.2 \\
\hline Total & & 31 & 45.7 & 49.6 & 17 \\
\hline
\end{tabular}


Table 5: Distribution of castes in the four fieldwork villages with average landholdings in brackets (in acres) (source: fieldwork data).

\begin{tabular}{|l|l|l|l|l|}
\hline & $\begin{array}{l}\text { Panchnagaram } \\
\text { (Dharwad) }\end{array}$ & $\begin{array}{l}\text { Kamlapur } \\
\text { (Dharwad) }\end{array}$ & $\begin{array}{l}\text { Shiva Camp } \\
\text { (Raichur) }\end{array}$ & $\begin{array}{l}\text { Jagalwara } \\
\text { (Raichur) }\end{array}$ \\
\hline $\begin{array}{l}\text { Dominant Caste Lingayats } \\
\text { (including some OBC Lingayat } \\
\text { sub-castes) }\end{array}$ & $47.6(3.74)$ & $11.6(4.97)$ & $2.2(1.5)$ & $14.5(3.98)$ \\
\hline Dominant Caste Marathas & 0 & $25.4(6.92)$ & 0 & 0 \\
\hline $\begin{array}{l}\text { Dominant Caste Reddys and } \\
\text { Kammas }\end{array}$ & 0 & 0 & $21.9(9)$ & 0 \\
\hline OBCs (Kurubas and Uppars) & $16.4(2.75)$ & $12.3(3.83)$ & $24.1(1.6)$ & $8(5.11)$ \\
\hline Muslims & $15.2(0.97)$ & $32.9(1.18)$ & 0 & $10.5(1.84)$ \\
\hline Scheduled Tribes & $12.5(2.3)$ & $2.7(1)$ & $12.4(1.5)$ & $45.2(2.9)$ \\
\hline Scheduled Castes & $8.3(0.22)$ & $13(0.9)$ & $37.2(0.42)$ & $20.2(1.2)$ \\
\hline Others & 0 & $2.1(6.33)$ & $2.2(2.2)$ & $1.6(3.25)$ \\
\hline Total & 100 & 100 & 100 & 100 \\
\hline
\end{tabular}

Table 6: Patterns of labouring class reproduction in the fieldwork villages (source: fieldwork data)

\begin{tabular}{|c|c|c|c|c|c|}
\hline & $\begin{array}{l}\text { Primary Basis of } \\
\text { Reproduction }\end{array}$ & $\begin{array}{l}\text { P'nagaram } \\
\text { (Dharwad) }\end{array}$ & $\begin{array}{l}\text { Kamlapur } \\
\text { (Dharwad) }\end{array}$ & $\begin{array}{l}\text { Shiva } \\
\text { Camp } \\
\text { (Raichur) }\end{array}$ & $\begin{array}{l}\text { Jagalwara } \\
\text { (Raichur) }\end{array}$ \\
\hline \multirow[t]{5}{*}{$\begin{array}{l}\text { Informal } \\
\text { Work Total }\end{array}$} & & 76.9 & 82 & 83.8 & 84.9 \\
\hline & $\begin{array}{l}\text { Casual Employment } \\
\text { (agriculture) }\end{array}$ & 48 & 25 & 59.8 & 61.9 \\
\hline & $\begin{array}{l}\text { Casual Employment } \\
\text { (commuting) }\end{array}$ & 22.6 & 50 & 0 & 0 \\
\hline & $\begin{array}{l}\text { Casual Employment } \\
\text { (circulation }- \text { non- } \\
\text { local) }\end{array}$ & 0 & 0 & 16.4 & 22.4 \\
\hline & $\begin{array}{l}\text { Regular Employment } \\
\text { (informal) }\end{array}$ & 6.3 & 7 & 7.6 & 0.6 \\
\hline $\begin{array}{l}\text { Formal } \\
\text { Work (total) }\end{array}$ & $\begin{array}{l}\text { Regular Employment } \\
\text { (formal) }\end{array}$ & 3.6 & 2 & 0 & 0 \\
\hline $\begin{array}{l}\text { Self- } \\
\text { Employment } \\
\text { (total) }\end{array}$ & & 16.6 & 14 & 14 & 13.4 \\
\hline \multirow[t]{2}{*}{$\begin{array}{l}\text { Self- } \\
\text { Employment }\end{array}$} & $\begin{array}{l}\text { Mix of farming } \\
\text { (agricultural } \quad P C P \text { ) } \\
\text { and wage-labour }\end{array}$ & 3.4 & 8 & 5.4 & 6.1 \\
\hline & $\begin{array}{l}\text { Non-agricultural } P C P \\
\text { (including } \\
\text { rearing) }\end{array}$ & 13.2 & 6 & 8.6 & 7.3 \\
\hline Total & & 100 & 100 & 100 & 100 \\
\hline
\end{tabular}


Table 7 Patterns of simple and expanded reproduction in Shiva Camp and Panchnagaram villages

\begin{tabular}{|c|c|c|c|c|}
\hline $\begin{array}{ll}\text { Type } & \text { of } \\
\text { Reproduction }^{83}\end{array}$ & Village (District) & $\begin{array}{l}\text { Village- } \\
\text { Based }\end{array}$ & $\begin{array}{l}\text { Nearby } \\
\text { Town/City }\end{array}$ & Remote City \\
\hline \multirow{2}{*}{$\begin{array}{l}\text { Expanded } \\
\text { Reproduction } \\
\text { through } \\
\text { accumulation } \\
\text { (Capitalist Class) }\end{array}$} & $\begin{array}{l}\text { Panchnagaram } \\
\text { (Dharwad) }\end{array}$ & $1^{\text {st }}$ & $2^{\text {nd }}$ & negligible \\
\hline & $\begin{array}{l}\text { Shiva Camp } \\
\text { (Raichur) }\end{array}$ & $1^{\text {st }}$ & $3^{\text {rd }}$ & $2^{\text {nd }}$ \\
\hline \multirow{2}{*}{$\begin{array}{l}\text { Simple } \\
\text { Reproduction } \\
\text { (Labouring Class) }\end{array}$} & $\begin{array}{l}\text { Panchnagaram } \\
\text { (Dharwad) }\end{array}$ & $1^{\mathrm{st}}$ & $2^{\text {nd }}$ & negligible \\
\hline & $\begin{array}{l}\text { Shiva Camp } \\
\text { (Raichur) }\end{array}$ & $1^{\text {st }}$ & negligible & $2^{\text {nd }}$ \\
\hline
\end{tabular}

\section{Notes}

${ }^{1}$ Bair, "Analysing Global Economic Organisation"; Gereffi, "The Organisation of Buyer-Driven Commodity Chains"; Gereffi et al. "The Governance of Global Value Chains"; Gibbon et al., "The Governance of Global Value Chains"; Newsome et al., Putting Labour in its Place, 7.

${ }^{2}$ Castree et al., Spaces of Work; Herod, Labour Geographies; Newsome et al., Putting Labour in its Place; Rainnie et al., "Review and Positions"; Selwyn, The Global Development Crisis, to name but a few.

${ }^{3}$ Newsome et al., Putting Labour in its Place, 13; Rainnie et al. "Review and Positions", 161.

${ }^{4}$ Thompson and Smith, "Debating Labour Process Theory", 11; and further back Braverman, Labor and Monopoly Capital; Burawoy, The Politics of Production.

${ }^{5}$ Newsome et al., Putting Labour in its Place, 14, 15.

${ }^{6}$ Rainnie et al., "Making Space for Geography", 299; Thompson and Smith "Debating Labour Process Theory", 13.

${ }^{7}$ The terms associational and structural power (of labour) were first developed by Wright, "WorkingClass Power". 'Structural' power 'results directly from tight labour markets' and 'from the strategic location of a particular group of workers within a key industrial sector' (Wright 2000, 962).

Associational power refers to labour's capacity to organize.

${ }^{8}$ eg. Selwyn, "Labour Flexibility in Export Horticulture".

9 eg. Riisgaard and Hammer, "Prospects for Labour".

${ }^{10}$ eg. Newsome et al., Putting Labour in its Place; Roesch et al. "Bonded Labour in Rice Mills".

${ }^{11}$ eg. Selwyn, "Labour Flexibility in Export Horticulture".

${ }^{12}$ Riisgaard and Hammer, "Prospects for Labour", 178; Silver, Forces of Labour.

${ }^{13}$ Pringle, Trade Unions in China.

${ }^{14}$ Rainnie et al., "Review and Positions", 164; Kapadia, "Mutuality and Competition".

${ }^{15}$ Newsome et al., Putting Labour in its Place, 7 drawing on Henderson et al., "Global Production Networks".

${ }^{16}$ Barrientos and Kritzinger, "Squaring the Circle".

${ }^{17}$ Selwyn, "Labour Flexibility in Export Horticulture".

${ }^{18}$ Rogaly et al., "Seasonal Migration".

${ }^{19}$ Riisgaard and Hammer, "Prospects for Labour". 
${ }^{20}$ Offices now located in the special economic zone that they worked on include those of ANZ, Microsoft, Nokia and IBM. No survey was conducted of the occupants of apartment blocks, but the location of most of these were in Ramagondonahalli and Devarabeesanahalli, close to Bangalore's Whitefields IT hub.

${ }^{21}$ The base of a commodity chain is hard to pin down. Agricultural inputs are produced upstream of farms, and all moments of production build upon the labour of past generations.

${ }^{22}$ Pattenden, Labour, State and Society, 41. For the more general point see also Harriss-White and Prosperi, "The Micro Political Economy of Gains", 41.

${ }^{23}$ Newsome et al., Putting Labour in its Place; Rainnie et al., "Review and Positions"; Selwyn, The Global Development Crisis.

${ }^{24}$ A variety of methods were used including surveys, ethnography, and household, group and key informant interviews.

${ }^{25}$ This literature is too voluminous to outline here but includes Brass, "Class Struggle"; Breman, "Labour Bondage"; Kapadia 1995, Siva and her Sisters; Lerche, "Politics of the Poor"; Patnaik "Class Differentiation"; Ramachandran, Wage Labour and Unfreedom; Rawal, "The Labour Process"; Srivastava, "Tenancy Contracts" on agricultural labourers, and Breman, Footloose Labour, Carswell and De Neve, "From Field to Factory"; Mosse et al., "On the Margins in the City"; Pattenden, "Migrating between"; Picherit, "The Shaping of Labour Struggles"; Rogaly et al., "Seasonal Migration" on circulating and commuting labourers.

${ }^{26}$ Anner, "Labour Control Regimes", Braverman, Labor and Monopoly Capital, Jonas, "Local Labour Control Regimes", Peck, Workplace.

${ }^{27}$ Castree et al., Spaces of Work; Coe, "Geographies of Production"; Herod, Labor Geographies, 2010; Rainnie et al., "Making Space", "Review and Positions".

${ }^{28}$ Banaji, Theory as History; Bernstein, Class Dynamics; see also Pattenden, Labour, State and Society, chapter 2 .

${ }^{29}$ Part of this line is adapted from Banaji, Theory as History, 5. See also Campling, "Debating Modes of Production", 4.

${ }^{30}$ Peck, Workplace; Jonas, "Local Labour Control Regimes".

${ }^{31}$ Marx, Capital.

32 The appropriation of part of the 'total social capital' by merchant capitalists at various points along commodity circuits is beyond the scope of this article (Banaji, Theory as History, 278; see also Harriss-White, Rural Commercial Capital).

${ }^{33}$ Jonas, "Local Labour Control Regimes", 325; Peck, Workplace; see also Anner, Labour Control Regimes.

${ }^{34}$ While being partially autonomous of capitalists. See, for example, Hensman, Workers, Unions for a discussion of state practices. See Pattenden, Labour, State and Society for a fuller discussion of the relationship between capital and the state.

${ }^{35}$ Figures rounded to the nearest million.

${ }^{36}$ Unionisation levels in the informal sector are low, and even though there are indications that they are rising, over 90 per cent remain unorganised (Agwarala, Informal Labor).

${ }^{37}$ NSS figures cited in Breman and Kannan, The Long Road, 2.

${ }^{38}$ Harriss-White, India Working.

${ }^{39}$ Harriss-White, "Capitalism and Poverty", 1243. The rate of expansion of non-agricultural employment fell in the 1990s and 2000s (compared to the 1970s and 1980s), and employment growth as a whole fell to 0.21 per cent in the latter half of the 2000s (Himanshu, "Employment trends", 48; Thomas, "India's Labour Market", 41).

${ }^{40}$ See, for example, Pattenden, Labour, State and Society, Chapter 2.

${ }^{41}$ Business Standard, "Rajasthan Assembly"; Indian Express, "Rajasthan shows way".

${ }^{42}$ Hensman, Workers, Unions, 99.

${ }^{43}$ Bernstein, "Is there an Agrarian Question".

${ }^{44}$ For example Lerche, "Politics of the Poor". 
${ }^{45}$ See also, for example, Carswell and De Neve, "From Field to Factory" on commuting, and Breman, Footloose Labour; Mosse et al., "On the Margins"; Pattenden, "Migrating between"; Rogaly et al, "Seasonal Migration" on circulation.

${ }^{46}$ Harriss, "Reflections on Caste and Class".

${ }^{47}$ See, for example, Kapadia, "Mutuality and Competition".

${ }^{48}$ See, for example, Gooptu and Harriss-White, "Mapping".

${ }^{49}$ Simple both because of the ways in which all forms of labour are gendered and stratified by age, and because this obscures petty commodity producers (see Pattenden, Labour, State and Society, Chapter 2). The labouring classes are net sellers of labour power who do not produce a surplus. They include households that primarily work on their own land, but who also work as wage-labourers; households that work more as wage-labourers than on their own land; and households that only work as wage-labourers. The capitalist class are net buyers of labour who tend to produce a surplus, and includes those who produce exclusively through hired labour, and those who produce predominantly with hired labour.

${ }^{50}$ Dharwad district was part of the British colonialists' Bombay Presidency, while Raichur formed part of the territory of the Nizam of Hyderabad until 1956.

${ }^{51}$ UNDP, Karnataka.

52 This was conducted in 2013-2014. In addition, a survey of over 200 scheduled caste households in four Raichur villages was carried out in 2010 and 2011 (two of the same villages and two additional villages), and several hundred interviews carried out over a protracted period in a number of villages across the districts. Circular migrants were interviewed in Bangalore in 2010.

${ }^{53}$ At least one child in the case of farmers with ten acres or more.

${ }^{54}$ Pattenden, "Gatekeeping", Labour, State and Society.

${ }^{55}$ Pattenden, "Social Protection".

${ }^{56}$ Pattenden, Labour, State and Society, Chapter 8.

${ }^{57}$ One of the joint ventures was with Brazilian capital, and the other with South Korean capital. Tata is one of India's largest and most prominent companies.

${ }^{58}$ Ninety per cent of scheduled caste households in semi-irrigated Jagalwara had migrated (in whole or in part) at some point in the 2000s, as opposed to around two thirds in fully irrigated Shiva Camp.

${ }^{59}$ Carswell and De Neve, "MGNREGA in Tamil Nadu"; Heller, The Labor of Development; Heyer, "Labour Standards".

${ }^{60}$ Epstein, South India; Rawal, "The Labour Process".

${ }^{61}$ Brass, "Class Struggle".

${ }^{62}$ Roesch et al., "Bonded Labour".

${ }^{63}$ Pattenden, "Social Protection".

${ }^{64}$ For example, Breman, Labour Bondage.

${ }^{65}$ see also Lerche, "Politics of the Poor".

${ }^{66}$ Bharadwaj, "A View on Commercialisation" 1985.

${ }^{67}$ Guerin et al., "Corridors of Migration"; Pattenden, "Migrating between".

68 Places where labourers gather to wait for employment.

${ }^{69}$ Circulation to Bangalore for just four months of the year has been found to increase annual household incomes by fifty per cent over village-based incomes (Pattenden, "Migrating between", 172).

${ }^{70}$ Pattenden, "Migrating between".

${ }^{71}$ Pattenden, "Migrating between".

72 interview, 5 October 2010.

72 Fieldwork, December 2013.

${ }^{74}$ Except in relation to labour-intensive high value floriculture where sharecropping arrangements were the norm.

${ }^{75}$ See also Da Corta and Venkateshwarlu, "Unfree Relations". 
${ }^{76}$ For the Karnataka-focused argument see Pattenden, "Gatekeeping". For the more general argument see Jonas "Local Labour Control Regimes", 327. Such strategies were not without historical precedent (Breman, Labour Bondage), but were now mediated through the state.

${ }_{77}$ Bourdieu, The Logic of Practice, 118.

${ }^{78}$ Pattenden, "Gatekeeping".

${ }^{79}$ See also Harriss-White, "Work and Wellbeing", 156.

${ }^{80}$ Pattenden, Labour, State and Society, Chapter 8.

${ }^{81}$ Pattenden, "Class and Social Policy".

${ }^{82}$ Irrigation levels were estimated by asking each household how much of their land was irrigated and by what means.

${ }^{83}$ Calculated by shares of income across capitalist and labouring class households respectively. 